Кривдіна Інна Борисівна доцент кафедри міжнародних відносин та права Одеського національного політехнічного університету, кандидат історичних наук, доцент, проспект Шевченко, 1, м. Одеса, 65044, тел.: (066) 970-90-40, e-mail: krivdina.inna@gmail.com, https://orcid.org/0000-0002-1472-3037

Латишева Вікторія Валентинівна доцент кафедри міжнародних відносин та права Одеського національного політехнічного університету, кандидат наук з державного управління, проспект Шевченко, 1, м. Одеса, 65044, тел.: (050) 490-28-15, e-mail: viktorialatiseva@gmail.com, https://orcid.org/0000-0002-6224-4030

\title{
АКТИВІЗАЦІЯ ПЕРЕГОВОРНОГО ПРОЦЕСУ ТА КОМУНІКАТИВНОЇ ВЗАЕМОДІЇ МІЖ ОРГАНАМИ ПУБЛІЧНОЇ ВЛАДИ ТА ГРОМАДСЬКІСТЮ НА РЕГІОНАЛЬНОМУ РІВНІ
}

Анотація. Стаття присвячена дослідженню сучасного стану комунікативної взаємодії між органами публічної влади та громадськістю на регіональному рівні, на прикладі застосування таких форм їх взаємодії, як громадські ради, громадські слухання та е-петиції.

Актуальність тематики статті підтверджується низкою грунтовних вітчизняних досліджень, щодо сучасного стану суб'єкт-суб'єктної взаємодії як на рівні окремих територіальних громад, так і на регіональному рівні.

Аналіз нормативно-правового регулювання (в тому числі - і локальноправового) та вітчизняної практики його застосування дозволив виявити його проблемні аспекти та запропонувати шляхи його удосконалення.

У процесі дослідження виявлено незадовільний стан правового, інституційного та кадрового забезпечення діяльності громадських рад, а також - значний рівень їх залежності від органів публічної влади.

У процесі дослідження встановлено неефективність використання регіональними органами виконавчої влади (щодо е-петицій) та органами місцевого самоврядування (щодо громадських слухань) відповідних форм взаємодії з громадськістю.

Ключовою проблемою всіх вищеозначених механізмів взаємодії $\epsilon$ формальне ставлення до них з боку органів влади.

Оскільки у більшості органів публічної влади відсутнє розуміння необхідності здійснення консультацій з громадськістю, і це при тому, що саме подібні консультації підвищують рівень легітимності прийнятих рішень.

А показником ефективності роботи відповідних рад $є$ не кількість проведених засідань, а кількість врахованих пропозицій розроблених 
відповідними радами.

Отже, у процесі інституалізації діяльності громадських рад та громадських слухань поки що не вдалося досягти належного рівня взаємодії органів публічної влади та громадськості.

Не вдалося досягти налагодження відповідного рівня суб'єкт- суб'єктної взаємодії і шляхом запровадження е-петиції, який мав всі шанси спростити та підвищити рівень відповідної комунікації.

Саме виявлений нами незадовільний стан комунікативної взаємодії між органами публічної влади та громадськістю свідчить не лише про необхідність удосконалення відповідної взаємодії, а й про можливість застосування сучасних практик переговорного процесу, у випадках коли комунікація зайшла в «глухий кут».

Ключові слова: громадські ради, громадські слухання, переговорний процес, комунікативна взаємодія, регіональне управління.

Kryvdina Inna Borysivna Associate Professor of the Department of International Relations and Law Odessa National Polytechnic University, Candidate of Historical Sciences, Associate Professor, Shevchenko Ave., 1, Odessa, 65044, tel.: (066) 970-90-40, e-mail: krivdina.inna@gmail.com, https://orcid.org/0000-0002-1472-3037

Latysheva Victoria Valentinovna Associate Professor of International Relations and Law, Odessa National Polytechnic University, Candidate of Science in Public Administration, Shevchenko Ave., 1, Odessa, 65044, tel .: (050) 490-28-15, e-mail: viktorialatiseva@gmail.com, https://orcid.org/0000-0002-6224-4030

\section{ACTIVATION OF THE NEGOTIATION PROCESS AND COMMUNICATIVE INTERACTION BETWEEN PUBLIC AUTHORITIES AND THE PUBLIC AT THE REGIONAL LEVEL}

Abstract. The article is devoted to the study of the current state of communicative interaction between public authorities and the public at the regional level, on the example of the use of such forms of their interaction as public councils, public hearings and e-petitions.

The relevance of the topic of the article is confirmed by a number of thorough domestic studies on the current state of subject-subject interaction, both at the level of individual territorial communities and at the regional level.

The analysis of normative-legal regulation (including local-legal) and domestic practice of its application allowed to reveal its problematic aspects and to suggest ways of its improvement.

The study revealed an unsatisfactory state of legal, institutional and staffing of public councils, as well as a significant level of their dependence on public authorities.

Also, the study found the inefficiency of the use of appropriate forms of interaction with the public by regional executive bodies (for e-petitions) and 
local governments (for public hearings.

The key problem of all the above mechanisms of interaction is the formal attitude to them on the part of the authorities.

Because most public authorities do not understand the need for public consultation, despite the fact that such consultations increase the legitimacy of decisions.

And, an indicator of the effectiveness of the relevant councils is not the number of meetings held, but the number of proposals developed by the relevant councils.

Thus, in the process of institutionalization of public councils and public hearings, it has not yet been possible to achieve the appropriate level of interaction between public authorities and the public.

It was not possible to establish an appropriate level of subject-subject interaction by introducing an e-petition, which had every chance to simplify and increase the level of appropriate communication.

It is our unsatisfactory state of communicative interaction between public authorities and the public that indicates not only the need to improve appropriate interaction, but also the possibility of applying modern practices of the negotiation process in cases where communication has reached a dead end.

Keywords: public councils, public hearings, negotiation process, communicative interaction, regional management.

Постановка проблеми. Продовження курсу на децентралізацію в Україні вимагає сьогодні від місцевих та регіональних органів влади не лише підвищення рівня комунікативної взаємодії влади та громадськості на місцях, а й пошуку нових форм та механізмів налагодження відповідної комунікації.

Сьогодні процес децентралізації протікає не рівномірно у різних територіальних громадах, спостерігаються громади, що активно включилися у вищезазначені процеси, так, i ті, що і досі залишаються пасивними.

Однією із причин, що призводить до виникнення подібної ситуації, $\epsilon$ низький рівень поінформованості населення щодо процесів, які відбуваються на рівні територіальної громади, та слабкий рівень залучення громадян до управлінських процесів.

Така ситуація породжує не лише пасивність та не розуміння мешканцями територіальних громад сучасних управлінських процесів, а й стає підгрунтям для виникнення численних конфліктних ситуацій.

Розв'язання зазначених ситуацій спонукає органи публічної влади на місцях як до пошуку нових форм та механізмів взаємодії з громадськістю, так i до використання вже традиційних інструментів, що застосовуються при розв'язанні конфліктних ситуацій, наприклад, опанування методиками та технологіями ведення переговорного процесу.

Взагалі, використання механізмів та технологій ведення переговорного процесу при розв'язанні управлінських конфліктів на сьогодні $\epsilon$ недооціненою органами публічної влади.

Разом 3 тим, налагодження ефективної комунікації з громадою за 
допомогою механізмів та технологій ведення переговорного процесу дозволяє, окрім налагодження ефективної комунікації, досягти таких додаткових цілей, як виявлення зацікавлених сторін, визначення кола їх інтересів, окреслення позицій сторін, встановлення критичних точок дискусії, визначення реального та потенціального рівнів довіри до органів публічної влади, погодження інтересів сторін, забезпечує пошук точок перетину, вироблення спільної позиції, посилення взаємоконтролю сторін та ін.

Аналіз останніх досліджень і публікацій. Різні аспекти проблеми забезпечення комунікативної взаємодії органів публічної влади 3 громадськістю досліджували такі вітчизняні вчені, як Драгомирецька Н. М., І. І. Колосовська, А. І. Кохан, М. В. Лациба, Л. В. Літвінова, М. Г. Левчук, Ю. І. Лях, О. В. Михайловська, В. І. Плохих, С. О. Романенко, К. М. Соляник, Ю. М. Стаскевич, В. С. Юрченко, Н. В. Шотурма та ін.

Перспективам використання переговорного процесу у державному управлінні присвячено публікацію Бондар Г. Л., проблемам медіації в публічному управлінні, в цілому, присвячено роботу С. Бородіна та ін.

Метою статті є дослідження сучасного стану комунікативної взаємодії між органами публічної влади та громадськістю на прикладі діяльності громадських рад, громадських слухань та е-петицій, а також обгрунтування можливості застосування сучасних технологій ведення переговорного процесу в рамках налагодження суб'єкт-суб'єктної взаємодії на регіональному рівні.

Виклад основного матеріалу. Головною умовою ефективної комунікації між владою та громадою $є$ усвідомлення всіма учасниками відповідної взаємодії факту, що вона є не лише обміном думок та інформації, ii основна мета полягає в забезпеченні зворотного зв'язку та вироблені спільної конструктивної позиції, щодо проблемних питань публічного управління.

В Україні вже тривалий час існує така форма владно-громадської взаємодії, як громадські ради.

За цей час неодноразово змінювалося нормативно-правове регулювання діяльності громадських рад та удосконалювалися підходи, щодо визначення їх діяльності.

Змінювався їх статус: від «постійно діючого консультативно-дорадчого органу» - до «тимчасового консультативно-дорадчого органу», і навпаки.

Звужувалися і розширювалися їх повноваження, змінювався суб'єктний склад громадських рад та вимоги до нього.

Наприклад, якщо на початковому етапі становлення громадських рад до ïх повноважень входило «створення умов для реалізації громадянами конституційного права на участь в управлінні державними справами»[1], то пізніше їх повноваження було звужено до «сприяння реалізації громадянами» відповідного права [2].

Також, якщо відповідно до Типового положення про громадські ради (2010 року), громадські ради мали можливість здійснювати громадський контроль всіх органів публічної влади, то відповідно до Типового положення 
(2015 року) - лише за діяльністю того органу при якому утворені.

Тим не менш, громадські ради є одним із реальних механізмів впливу громадськості на діяльність органу публічної влади.

Керуючись наданими їм повноваженнями громадські ради мають цілу низку інструментів для отримання ними доступу до інформації за допомогою інформаційних запитів, відкритих даних, гарячих ліній; оприлюднення ними інформації про їх діяльність на веб-сайтах органів публічної влади; впливу на процеси ухвалення управлінських рішення шляхом розробки та подання власних пропозиція, в тому числі рекомендації, щодо звітів органів публічної влади; вони наділені правом звернення до депутатів всіх рівнів, в тому числі і до народних депутатів України; мають можливість брати участь у роботі депутатських комісій та бути присутніми на їх засіданнях; беруть участь у розробці нормативно-правових актів, та здійснюють їх експерту оцінку та супровід; можуть виступати ініціаторами громадського обговорення 3 питань, що стосуються діяльності відповідної ради; брати участь у громадських слуханнях та інших формах консультацій 3 громадськістю; можуть бути, як організаторами, так і учасниками мирних зібрань, в тому числі, у разі використання всіх вищеозначених форм, члени громадських рад мають право на звернення до суду.

Таким чином, громадські ради сьогодні мають можливість напряму донести до органів публічної влади власну думку та бачення розв'язання важливих для суспільства проблем, а й проконтролювати та застерегти органи влади від прийняття хибних рішень, що можуть зашкодити інтересам, як територіальної громади так, і суспільства, в цілому.

Діючи на основі Постанови Кабінету Міністрів «Про забезпечення участі громадськості у формуванні та реалізації державної політики», якою затверджено типове положення про громадські ради [1], останні зміни до неї було внесено у 2019 році [2].

У цілому, для правового регулювання діяльності громадських рад характерним є локально-правове регулювання, що здійснюється на підставі статутів та регламентів.

Тобто, вищеозначена Постанова лише окреслює загальні правові рамки, відтоді, як кожен орган публічної влади розробляє окремий локальноправовий акт, що деталізує порядок функціонування конкретної ради.

Станом на 3 квартал 2019 року громадські ради було створено при 72 органах публічної влади, а саме, 15 Міністерствах, 35 Центральних органах виконавчої влади та 22обласних державних адміністраціях [3].

Громадські ради у своїй діяльності стикаються із значної кількістю проблем інституційного характеру.

У першу чергу вони пов'язані 3 якістю їх кадрового забезпечення та рівнем фахової підготовки їх членів, обмеженістю їх повноважень та відсутність системності в їх роботі.

Так, за даними звіту підготовленого Кабінетом Міністрів України за підсумками роботи по взаємодії органів виконавчої влади з громадськими радами у 3 кварталі 2019 року, із 72 громадських рад, що діють на сьогодні - 
20 відсотків із них не провели жодного засідання, 24 відсотки провели 1 засідання, 12 відсотків - 2 засідання, і лише 9 відсотків громадських провели більше ніж 3 засідання. [3]

Безумовно, така кількість проведених засідань свідчить про неефективність організації роботи громадських рад.

I це притому, що наразі відсутні дані щодо ефективності діяльності громадських рад, засідання яких все ж таки відбулося.

Проблемним аспектом діяльності більшості громадських рад на рівні місцевого самоврядування є залучення доволі вузького кола представників громадських організацій до участі в їх діяльності.

Як правило, процес формування кадрового складу відповідних рад відбувається формально та не прозоро.

Більше того, члени відповідних громадських рад не лише позбавлені реального впливу на діяльність органів публічної влади, кадровий склад подібних рад підбирається свідомо, та $є$ частково залежним від органу публічної влади.

Наприклад, кадровий склад громадської ради, що сформований при Полтавській районній раді, хоч і відповідає вимогам чинного законодавства (тобто не перевищує 35 осіб), але представлений членами двох організацій, а саме - місцевою радою ветеранів та радою директорів шкіл [4, с. 18].

Натомість, прикладом ефективної роботи по прозорому формуванню складу громадської ради можна навести підхід до формування громадської ради застосований Управлінням екології Департаменту ЖКГ Миколаївської міської ради.

Так, на запит громадськості щодо погіршення в м. Миколаєві ситуації щодо незаконної вирубки зелених насаджень через соціальні мережі (на сторінці Департаменту в мережі «Фейсбук») було оголошено відкритий конкурс та запрошено всіх бажаючих долучитися до вирішення проблеми.

Тим самим було створено пул громадських організацій, члени яких у подальшому і утворили відповідну громадську раду. [4, с. 21]

Разом 3 тим, підвищення ефективності діяльності громадських рад вимагає від всіх учасників цього процесу налагодження конструктивної співпраці та взяття на себе відповідальності за розробку і прийняття відповідних рішень.

Ще однією формою забезпечення ефективної комунікації 3 громадськістю на рівні місцевого самоврядування є проведення громадських слухань.

За даними Національного опитування щодо громадського залучення, яке проводилося влітку 2020 року в рамках Програми сприяння громадській активності «Долучайся» та фінансується Агентством США 3 міжнародного розвитку (USAID), на сьогодні лише 6,7 \% громадян України брали участь у громадських слуханнях [5].

Правове регулювання проведення громадських слухань визначено в Законі України «Про місцеве самоврядування» [6], а конкретизація порядку їх проведення здійснюється на підставі статутів територіальних громад. 
У рамках даного дослідження розглянемо практику організації та проведення громадських слухань у містах Вінниця та Львів.

Так, у статуті м. Львова громадські слухання визначаються, як: «форма співпраці міської ради та мешканців міста» [7].

При цьому, предметом обговорення можуть бути будь-які проблеми життєдіяльності міста.

В обов'язковому порядку на громадське обговорення виносяться питання щодо затвердження плану території, плану зонувань та генерального плану забудови.

Також, на громадські слухання виносяться питання формування місцевого бюджету.

Цікавим $є$ те, що ініціатором проведення громадських слухань у Львові $є$ будь-який повнолітній житель міста.

У «Правилах проведення громадських слухань міста Львів» [8], що є додатком до статуту територіальної громади, визначено чіткий перелік документів, який необхідно подати разом 3 повідомленням про ініціювання громадських слухань, а також - зібрати підписи не менше, як 75 жителів міста.

У п’ятиденний термін після вивчення питання секретаріат Львівської міської ради визначається 3 датою проведення громадських слухань та розміщує відповідну інформацію на офіційному веб-сайті Львівської міської ради.

Так, на сайті Львівської міської ради є окрема колонка під назвою «Громадські слухання».[9]

При цьому, проведення громадських слухань здійснюється не раніше 10 днів та не пізніше 25 днів 3 дня надходження звернення про ініціювання відповідного слухання.

Важливо, що під час розгляду вузькоспеціалізованих питань реєстрація учасників не проводиться, у разі розгляду питання загальноміського значення - проводиться реєстрація на підставі документа, що посвідчує особу.

Реєстрація юридичних осіб здійснюється на підставі документу, що посвідчує особу та належним чином оформленої довіреності на представництво, а також, документу про реєстрацію юридичної особи на території м. Львів.

При цьому, належним чином зареєстрований учасник отримує мандат для голосування.

Традиційним $\epsilon$ проведення громадських слухань i для м. Вінниця. «Положення про проведення громадських слухань у місті Вінниця» визначає громадські слухання як: «одну 3 форм безпосередньої участі членів територіальної громади у здійсненні повноважень місцевого самоврядування, які передбачені статтею 13 Закону України «Про місцеве самоврядування в Україні» [6].

На відміну від м. Львів, у ст. 5 Положення про проведення громадських слухань у м. Вінниця [10] чітко визначено перелік питань, що можуть бути предметом громадських слухань. 
Відрізняється від львівської моделі і визначення підходів до ініціювання громадських слухань. Так, у м. Вінниця ініціювати громадські слухання може: ініціативна група членів територіальної громади від 3 до 10 осіб обрана на зборах громади; не менше трьох громадських об'єднань, благодійних організацій, об'єднань співвласників багатоквартирних будинків, органів самоорганізації населення; група депутатів міської ради в кількості не менше мінімального чисельного складу постійної комісії, встановленого Регламентом ради; постійна комісія міської ради; виконавчий орган міської ради; міський голова ( ст. 7 Положення) [10].

Відрізняється і кількість підписів, необхідних для реєстрації ініціативи, щодо проведення громадських слухань. Так, для загальноміських слухань необхідно набрати 800 підписів, для місцевих (мікрорайон - квартал вулиця), відповідно: 400 - 300 - 150 ( ст. 9 Положення) [10].

Відповідно до ст. 12 даного Положення, для підготовки та проведення громадських слухань утворюється підготовчий комітет.

Відповідь про початок підготовки та проведення громадських слухань, до його ініціатора повинна надійти в триденний термін.

Під час проведення громадських слухань також здійснюється реєстрація, під час якої посвідчення особи не вимагається.

При цьому відмічається, що незареєстровані учасники мають право лише дорадчого голосу (де дорадчий голос потрактовується як право брати участь у громадських слуханнях без можливості голосування).

Рішення приймаються більшістю голосів (на відміну від м. Львів, де рішення вважається прийнятим, якщо за нього проголосувала більше ніж половина учасників).

Досліджувані нами положення та правила проведення громадських слухань в м. Львів та Вінниця $є$ одними із кращих практик застосування відповідного механізму здійснення комунікативної взаємодії органів публічної влади.

При цьому, кожен із розглянутих нами актів локально-правового регулювання має, як свої переваги, так і недоліки.

Так, на нашу думку, «Правила проведення громадських слухань у місті Львів» $є$ більш демократичними, а ніж «Положення про громадські слухання у місті Вінниця».

При цьому, останнє Положення більш деталізоване та структуроване, та містить чітку процедуру ініціювання, організації та проведення громадських слухань.

Тим не менш, краща вітчизняна практика застосування та правового регулювання громадських слухань свідчить про перспективність подальшого застосування відповідного механізму комунікативної взаємодії влади та громадськості.

Разом 3 тим, варто уникати формального підходу при підготовці та затвердженні відповідних Положень про проведення громадських слухань.

Відповідні Положення мають бути чіткими, зрозумілими, прозорими та максимально доступними для розуміння. 
Також, доцільним видається максимальне розширення переліку питань, що можуть бути предметом обговорень на громадських слуханням.

Має бути визначено коло питань, обговорення яких є обов'язковим.

До обов’язкового переліку питань ми пропонуємо включити, такі: питання щодо реконструкції центральної частини міста (особливо, якщо вона $\epsilon$ одночасно і історичним центром міста), визначення тарифів на воду та електроенергію, землевпорядкування, захоронення на території місцевої громади відходів промисловості та побудови заводів 3 переробки відходів, обговорення проекту місцевого бюджету та затвердження генеральних планів та ін.

Наступною формою забезпечення взаємодії влади та громадськості $€$ інститут права на звернення громадян, який закріплено в ст. 40 Конституції України [11], та яка деталізується Законом України «Про звернення громадян» [12].

Даний нормативно-правовий акт визначає коло осіб, що мають право звернення, встановлює вимоги до звернення, види звернень, встановлює порядок та терміни розгляду звернень, а також, передбачає відповідальність посадових осіб за порушення Закону України «Про звернення громадян» та iH.

У 2015 році в Україні було внесено зміни до Закону України «Про звернення громадян» та запроваджено нову форму звернень, а саме електронна петиція.

Запровадження електронної петиції (далі - е-петиція) є позитивним кроком, що вдосконалює процес взаємодії держави та громадян. Ст. 5 Закону України «Про звернення громадян», визначає електронну петицію, як особливу форму колективного звернення [12].

До того ж, на нашу думку, е-петиція, $\epsilon$ найпростішою формою громадського контролю та громадської участі, оскільки потребує від громадян мінімальних зусиль щодо ii подачі. Запровадження е-петицій удосконалило не лише спосіб подачі петиції, а й скоротило терміни їх розгляду.

Так, якщо термін розгляду звичайного звернення від 30 до 45 днів, то розгляд е-петиції здійснюється невідкладно або ж протягом 10 днів [12].

Перевагою е-петицій $є$ залучення широкого кола громадськості до процесу підписання петиції, що, безумовно, підвищує рівень поінформованості громадян та активізує громадську участь.

Сама процедура подання е-петиції передбачає декілька етапів: ініціювання петиції, перевірка петиції, оприлюднення та збір підписів на підтримку петиції.

Про значну зацікавленість громадськості у використанні саме відповідного механізму здійснення ГК діяльності органів публічної влади свідчить той факт, що лише за рік запровадження відповідного механізму до обласних державних адміністрацій надійшло близько 11 тис. петицій [13].

Станом на 01.06.2020 року найбільше всього е-петицій надійшло на сайт Президента України - понад 49 тисяч, що становить 92 відсотки від загальної 
кількості петицій, для порівняння до Верховної Ради України подано 2093 петиції; до Кабінету Міністрів України - 2208. При цьому, необхідні голоси для розгляду е-петиції набирає лише 0,16 відсотки з загальної кількості поданих. За результатами розгляду петицій проблему вирішено, фактично, лише у 22 відсотках петицій, не підтримано - 22 відсотки, 47 відсотків направлено на вирішення до інших органів публічної влади [14].

Проблемним аспектом подання е-петицій $є$ збір підписів на підтримку петиції у тому випадку, коли суб’єктом подання петиції є орган місцевого самоврядування.

Оскільки ст. 23 з позначкою 1 Закону України «Про внесення змін до Закону України «Про звернення громадян» щодо електронного звернення та електронної петиції» [15] визначає, що вимоги, щодо кількості підписів епетиції, яка подається до органу місцевого самоврядування визначається статутом територіальної громади.

Так як процес розробки та прийняття статутів територіальних громад йде дуже повільно, відсутність визначеності у цій правовій нормі створює передумови для маніпулювання нею шляхом встановлення завищеної прохідної кількості голосів.

Таким чином, можемо дійти висновку, що попри всю прогресивність зазначеного механізму взаємодії він досі не став ефективним інструментом здатним реально вплинути на діяльність органів публічної влади.

Більше того, подальше ігнорування відповідного механізму, реалізація та ефективність використання якого викликає значну зацікавленість у суспільстві, може мати негативні наслідки.

Слід зазначити, що небажання органів публічної влади використовувати цивілізовані форми суб'єкт-об'єктної взаємодії змушує громадськість до застосування більш жорстких форм, наприклад, проведення мітингів протесту.

Крім цього, зневіра громадян у використанні механізму е-петиції, підриває рівень довіри громадян до влади та значно погіршує іiі імідж.

Вміння слухати $\epsilon$ одним із основних принципів ефективного переговорного процессу.

3 метою недопущення негативної реакції з боку громадян, громадських об’єднань та інших суб'єктів комунікативної взаємодії, органам публічної влади слід намагатися якомога частіше ініціювати переговорний процес 3 метою розв'язання нагальних питань, що виникають в процесі здійснення ними владних повноважень та громадськістю.

Висновки. Отже, все вищезазначене дозволяє нам зробити висновок про необхідність активізації комунікативної взаємодії між органами публічної влади та громадськістю на регіональному рівні.

Досліджувані нами форми комунікативної взаємодії між органами публічної влади та громадськістю, а саме діяльність громадських рад, громадські слухання та електронні петиції, поки ще не стали ефективним механізмом суб’єкт-об’єктної взаємодії між владою та громадськістю.

Що дозволяє нам зробити висновок про необхідність вдосконалення вже 
існуючих форм взаємодії та налагодження ефективного переговорного процесу між ними.

Вміння слухати та вміння бути почутим, на теперішньому етапі комунікативної взаємодії між органами публічної влади та громадськістю, сьогодні має стати «наріжним каменем» відповідної комунікації.

\section{Лimepamypa:}

1. Деякі питання щодо забезпечення участі громадськості у формуванні та реалізації державної політики: Постанова Кабінету Міністрів України від 3 листопада 2010 p. № 996. - Редакція від 07.05.2019, підстава - 353-2019-п. URL : https://zakon.rada.gov.ua/laws/show/996-2010-\%D0\% BF\#Text (дата звернення: 26.03.2021)

2. Про внесення змін до постанови Кабінету Міністрів України від 3 листопада 2010 р. № 996: Постанова Кабінету Міністрів України від 24 квітня 2019 р. № 353. URL : https://zakon.rada.gov.ua/laws/show/353-2019-\%D0\%BF\#Text (дата звернення: 26.03.2021)

3. Інформація про взаємодію органів виконавчої влади з громадськими радами протягом III кварталу 2019 року. URL : https://www.kmu.gov.ua/storage/app/sites/1/17-civik2018/rubrik_grom-rad/info-ovv-gr-3-2019.pdf (дата звернення: 26.03.2021)

4. Збірник звітів за результатами оцінки діяльності органів виконавчої влади за напрямком «взаємодія з громадськістю»: Збірка / Упоряд.: Любов Паливода - К.: [БФ «Творчий центр ТЦК»]. - 2018. - 72 с.

5. Допоможи собі сам: українці розчаровані в реформах, але готові підтримувати одне одного та свої громади: Національне опитування щодо громадського залучення. URL : https://dif.org.ua/article/dopomozhi-sobi-sam-ukraintsi-rozcharovani-v-reformakh-ale-gotovipidtrimuvati-odne-odnogo-ta-svoi-gromadi (дата звернення: 26.03.2021)

6. Про місцеве самоврядування в Україні: Закон України від 21.05.1997. № 280/97BP. - - Редакція від 23.07.2020, підстава - 805-IX . URL: https://zakon.rada.gov.ua/laws/show/280/97-\%D0\%B2\%D1\%80\#Text (дата звернення: 28.03.2021)

7. Статут територіальної громади м. Львова зареєстровано 27.12.2017 (наказ Головного територіального управління юстиції у Львівській області Міністерства юстиції України від 27.12.2017 № 645/6, Свідоцтво про державну реєстрацію Статуту територіальної громади м. Львова від 27.12.2017 № 5). URL: https://www8.cityadm.lviv.ua/inTEAM/Uhvaly.nsf/a19074bb3a9b23eac2256ac40046fcb4/79bc163468782e76c22 581f60034ff08?OpenDocument (дата звернення: 28.03.2021)

8. Правила проведення громадських слухань у м. Львові URL: https://cityadm.lviv.ua/public-hearings/253189-pravyla-provedennia-hromadskykh-slukhan-u-mlvovi\#: :text (дата звернення: 28.03.2021)

9. Офіційний веб-сайт Лівівської міської ради. URL : https://city-adm.lviv.ua/ publichearings (дата звернення: 28.03.2021)

10. Положення про громадські слухання у місті Вінниця затверджене рішенням міської ради від 30.09.2016 р. № 395, зі змінами .URL : https://www.vmr.gov.ua/ TransparentCity/ ContentLibrary/962bed5e-90d9-4ed7-9661-fbd07d109688/1(дата звернення: 28.03.2021)

11. Конституція України: Прийнята на п'ятій сесії Верховної ради України 28 червня 1996 р. Із змінами внесеними Законом України від 8 грудня 2004 р. № 2222I - VI. Станом на 1 січня 2006 р. - К., - 2006. - 124 с.

12. Про звернення громадян: Закон України від 2 жовтня 1996 року. № 393/96-ВР. Редакція від 01.01.2020, підстава - 198-IX URL : https://zakon.rada.gov.ua/laws/show/393/96$\% \mathrm{D} 0 \% \mathrm{~B} 2 \% \mathrm{D} 1 \% 80 \#$ Техt(дата звернення: 28.03.2021)

13. Колесников О. Електронні петиції у системі місцевої демократії: досвід обласних центрів України: аналітичні матеріали / О. Колесников // підготовлено за 
сприяння Асоціації сприяння самоорганізації населення. URL : https://samoorg.com.ua/wpcontent/uploads/2017/ 02/ Petitsiyi_gotov-1.pdf (дата звернення: 28.03.2021)

14. Голос народу до слуг народу. Скільки, кому і про що подають петиції? URL :. https://voxukraine.org/uk/golos-narodu-do-slug-narodu-skilki-komu-i-pro-shho-podayut-petitsiyi/ (дата звернення: 28.03.2021)

15. Про внесення змін до Закону України «Про звернення громадян» щодо електронного звернення та електронної петиції: Закон України від 2 липня 2015 року № 577-VIII. URL : https://zakon.rada.gov.ua/ laws/show/577-19\#n17 (дата звернення: 28.03.2021)

\section{References:}

1. Postanova Kabinetu Ministriv Ukrainy "Deiaki pytannia shchodo zabezpechennia uchasti hromadskosti u formuvanni ta realizatsii derzhavnoi polityky" : vid 3 lystopada 2010 r., № 996 [Resolution of the Cabinet of Ministers of Ukraine "Some issues regarding public participation in the formation and implementation of state policy" from November 32010 , № 996]. zakon.rada.gov.ua. Retrieved from https://zakon.rada.gov.ua/laws/show/996-2010$\%$ D0\%BF\#Text [in Ukrainian].

2. Postanova Kabinetu Ministriv Ukrainy "Pro vnesennia zmin do postanovy Kabinetu Ministriv Ukrainy vid 3 lystopada 2010 r. № 996” : vid 24 kvitnia 2019 r., № 353 [Resolution of the Cabinet of Ministers of Ukraine "On amendments to the Resolution of the Cabinet of Ministers of Ukraine of November 3, 2010 № 996" from April 24 2019, № 353]. zakon.rada.gov.ua. Retrieved from https://zakon.rada.gov.ua/laws/show/353-2019$\%$ D0\%BF\#Text [in Ukrainian].

3. Informatsiia pro vzaiemodiiu orhaniv vykonavchoi vlady $\mathrm{z}$ hromadskymy radamy protiahom III kvartalu 2019 roku [Information on the interaction of executive bodies with public councils during the third quarter of 2019]. (n.d.). www.kmu.gov.ua. Retrieved from https://www.kmu.gov.ua/storage/app/sites/1/17-civik-2018/rubrik_grom-rad/info-ovv-gr-32019.pdf [in Ukrainian].

4. Palyvoda, L. (Eds.). (2018). Zbirnyk zvitiv za rezultatamy otsinky diialnosti orhaniv vykonavchoi vlady za napriamkom «vzaiemodiia z hromadskistiu» [Collection of reports on the results of the evaluation of the activities of executive bodies in the direction of "interaction with public"]. Kyiv: BF «Tvorchyi tsentr TTsK» [in Ukrainian].

5. Dopomozhy sobi sam: ukraintsi rozcharovani v reformakh, ale hotovi pidtrymuvaty odne odnoho ta svoi hromady: Natsionalne opytuvannia shchodo hromadskoho zaluchennia [Help yourself: Ukrainians are disappointed in the reforms, but ready to support each other and their communities: National survey on public involvement]. (2020). dif.org.ua. Retrieved from https://dif.org.ua/article/dopomozhi-sobi-sam-ukraintsi-rozcharovani-v-reformakh-ale-gotovipidtrimuvati-odne-odnogo-ta-svoi-gromadi [in Ukrainian].

6. Zakon Ukrainy "Pro mistseve samovriaduvannia v Ukraini" : vid 21.05.1997, № 280/97-VR [Law of Ukraine "On local self-government in Ukraine" from 21.05.1997, № 280/97-BP]. zakon.rada.gov.ua. Retrieved from https://zakon.rada.gov.ua/laws/show/280/97\%D0\%B2\%D1\%80\#Text [in Ukrainian].

7. Ukhvala Lvivskoi Miskoi Rady "Pro Statut terytorialnoi hromady m. Lvova" : vid 07.12.2017, № 2667 [Decision of the Lviv City Council “On the Charter of the Territorial Community of the City of Lviv" from 07.12.2017, № 2667]. www8.city-adm.lviv.ua. Retrieved from https://www8.city-adm.lviv.ua/inTEAM/Uhvaly.nsf/a19074bb3a9b23eac2256ac40046fcb4/79bc16 3468782e 76c22581f60034ff08?OpenDocument [in Ukrainian].

8. Pravyla provedennia hromadskykh slukhan u m. Lvovi [Rules for holding public hearings in Lviv]. (n.d.). city-adm.lviv.ua. Retrieved from https://city-adm.lviv.ua/publichearings/253189-pravyla-provedennia-hromadskykh-slukhan-u-m-lvovi\#: :text [in Ukrainian]. 
9. Hromadski slukhannia [Public hearings]. city-adm.lviv.ua. Retrieved from https://cityadm.lviv.ua/public-hearings [in Ukrainian].

10. Rishennia miskoi rady "Polozhennia pro hromadski slukhannia u misti Vinnytsia, zi zminamy" : vid 30.09.2016 r., № 395 [Decision of the city council "Regulations on public hearings in the city of Vinnytsia, with changes" from 30.09.2016, № 395]. www.vmr.gov.ua. Retrieved from https://www.vmr.gov.ua/TransparentCity/ContentLibrary/962bed5e-90d9-4ed7-9661-fbd07d109688/1/ Положення\%20про\%20громадські\%20слухання\%203і\%20змінами.pdf [in Ukrainian].

11. Konstytutsiia Ukrainy : vid 28 chervnia $1996 r$. [The Constitution of Ukraine from June 28, 1996]. (2006). Kyiv [in Ukrainian].

12. Zakon Ukrainy "Pro zvernennia hromadian” : vid 2 zhovtnia 1996 roku, № 393/96-VR [Law of Ukraine “On citizens' appeals" from October 2 1996, № 393/96-BP]. zakon.rada.gov.ua. Retrieved from https://zakon.rada.gov.ua/laws/show/393/96-\%D0\%B2\%D1\%80\#Text [in Ukrainian].

13. Kolesnykov, O. (2017). Elektronni petytsii u systemi mistsevoi demokratii: dosvid oblasnykh tsentriv Ukrainy: analitychni materialy [Electronic petitions in the system of local democracy: the experience of regional centers of Ukraine]. samoorg.com.ua. Retrieved from https://samoorg.com.ua/wp-content/uploads/2017/02/Petitsiyi_gotov-1.pdf [in Ukrainian].

14. Moshniaha, N. (2020). Holos narodu do sluh narodu. Skilky, komu i pro shcho podaiut petytsii? [The voice of the people to the servants of the people. How many, to whom and about what petitions are submitted?]. voxukraine.org. Retrieved from https://voxukraine.org/uk/golosnarodu-do-slug-narodu-skilki-komu-i-pro-shho-podayut-petitsiyi/ [in Ukrainian].

15. Zakon Ukrainy "Pro vnesennia zmin do Zakonu Ukrainy «Pro zvernennia hromadian" shchodo elektronnoho zvernennia ta elektronnoi petytsii” : vid 2 lypnia 2015 roku, № 577-VIII [Law of Ukraine "On Amendments to the Law of Ukraine "On Citizens' Appeals" concerning Electronic Appeals and Electronic Petitions” from July 2 2015, № 577-VIII]. zakon.rada.gov.ua. Retrieved from https://zakon.rada.gov.ua/ laws/show/577-19\#n17 [in Ukrainian]. 